Available online on 15.04 .2020 at http://jddtonline.info
Open Access to Pharmaceutical and Medical Research
unrestricted non-commercial use, provided the original work is properly cited

Open 2 Access

Research Article

\title{
Flavonoid Compounds from Zanthoxylum leprieurii Guill. et Perr (Rutaceae) Extracts and their Antioxidant Activity against ABTS ${ }^{\bullet+}$
}

Yoro Tine ${ }^{* 1,2}$, Alioune Diallo ${ }^{1,2}$, Idrissa Ndoye ${ }^{1}$, Yin Yang2 ${ }^{2}$ Franck Renucci², Rokhya Sylla Guèye1, Mamadou Baldé1, Adama Diédhiou', Djibril Fall' ${ }^{1}$, Matar Seck ${ }^{1}$, Jean-Marie Desjobert ${ }^{2}$, Jean Costa ${ }^{2}$, Alassane Wélé ${ }^{1}$ and Julien Paolini²

${ }^{1}$ Laboratoire de Chimie Organique et Thérapeutique, Faculté de Médecine, Pharmacie et Odontologie, Université Cheikh Anta Diop, BP : 5005 Dakar-Fann, Sénégal

2 Université de Corse, UMR CNRS 6134 SPE, Laboratoire de Chimie des Produits Naturels, Campus Grimaldi, BP 52, F-20250 Corte, France

\begin{abstract}
Screening of flavonoid compounds in fruit, leaf, stem and root bark extracts of $Z$. leprieurii was achieved by liquid chromatography (LC) coupled with tandem mass spectrometry (MS ${ }^{2}$. Among the 186 reference compounds tested, four flavonoids were identified in one or other of the organ extracts from each plant (fruit, leaf, root barks and stem): neodiosmin and hesperidin were identified in all extracts. The presence of datiscin was reported only in leaves while that of rutin was identified in fruits and leaves. Of these four flavonoids, three (neodiosmin, datiscin and rutin) are detected for the first time in $Z$. leprieurii. The antioxidant properties of different extracts were tested regarding their scavenging activities on ABTS $^{\bullet+}$ radical. Fruit, leaf and stem extracts had low antioxidant potential and root bark extracts exhibited very low antioxidant activity.
\end{abstract}

Keywords: Zanthoxylum leprieurii, flavonoids, LC-MS/MS and antioxidant activity.

Article Info: Received 16 Feb 2020; Review Completed 20 March 2020; Accepted 29 March 2020; Available online 15 April 2020

\section{Cite this article as:}

Tine Y, Diallo A, Ndoye I, Yang Y, Renucci F, Guèye RS, Baldé M, Diédhiou A, Fall D, Seck M, Desjobert J, Costa J, Wélé A, Paolini J, Flavonoid Compounds from Zanthoxylum leprieurii Guill. et Perr (Rutaceae) Extracts and their Antioxidant Activity against ABTS॰+, Journal of Drug Delivery and Therapeutics. 2020; 10(2-s):120-124 http://dx.doi.org/10.22270/jddt.v10i2-s.4010

\section{*Address for Correspondence:}

Yoro Tine, Laboratoire de Chimie Organique et Thérapeutique, Faculté de Médecine, Pharmacie et Odontologie, Université Cheikh Anta Diop, BP: 5005 Dakar-Fann, Sénégal

\section{INTRODUCTION}

Phenolic compounds, such as phenolic acids and flavonoids are widely distributed in nature and are the most abundant antioxidants in the diet; they are the common components of fruits, vegetables, and its derivatives. The biological effects derived from phenolic compounds have been attributed to their antioxidant activity. The importance of the antioxidant constituents of plant materials for health and protection from coronary heart disease and cancer is also raising interest among scientists, food manufacturers, and consumers as the trend of the future is moving toward functional food with specific health effects. Potential sources of antioxidant compounds have been searched in several types of plant materials such as vegetables, fruits, leaves, oil seeds, cereal crops, barks and roots, spices and herbs, and crude plant drugs [1-4].

Belonging to the Rutaceae family, Zanthoxylum leprieurii is a deciduous aromatic tree distributed in Central and West Africa [5]. It is used in herbal medicine for the treatment of malaria, urinary infections, rheumatic pain, skin infections, intestinal parasites, sickle cell anemia, stomach disorders and

ISSN: 2250-1177 dysentery [5-7]. In Cameroon, the dried fruits are traditionally used as a spice in soups [8]. Literature has also shown that extracts of this plant possess a potential antimicrobial [9-13], insecticidal [14], antiplasmodial [15], cytotoxic [16,17], anti-inflammatory [18] and antioxidant activities [18-20].

Like many species of the Rutaceae family, flavonoids are mainly represented in the genus Zanthoxylum by flavones, flavonols and flavanones, which can be glycosylated and / or polymethoxylated $[4,21]$. Only one study have been carried out on the chemical composition of $Z$. leprieurii flavonoids [5], while the number of articles dealing with this subject is relatively important for other species of the Zanthoxylum genus. Other phytochemical studies on $Z$. leprieurii revealed the presence of diterpenes [22], alkaloids [15,16,23-27], amides [27] and coumarins [11,15,27] in solvent extracts from various organs (root, stem, leaf and fruit). Moreover, some papers were reported the chemical composition and biological activities of fruit essential oils [9-11,18,28-32] from various geographical origins such as Nigeria and Cameroun. Furthermore, its antioxidant activity has been 
described in two works. Bouba et al. (2010) have been reported good antioxidant activity of fruit extracts from $Z$. leprieurii [19]. Womeni et al. (2013) have shown that fruit extracts from $Z$. leprieurii considerably inhibits the oxidation of crude soybean oil [20].

Therefore, the present study was designed to qualitative determination of flavonoids in fruit, leaf, stem and root bark extracts of $Z$. leprieurii from Senegal using liquid chromatography (LC) coupled with tandem mass spectrometry $\left(\mathrm{MS}^{2}\right)$. The antioxidant activities of these extracts were also determined using ABTS ${ }^{\bullet+}$ method.

\section{MATERIAL AND METHODS}

\section{Solvents}

Methanol (HPLC grade) and hexane (HPLC grade) used for sample extraction, were purchased from Fisher Scientific (Illkirch, France). The solvents used for liquid chromatography were LC-MS grade acetonitrile (ACN), obtained from Fisher Scientific. Deionized water was purified using a Milli-Q water (Millipore, Bedford, MA, USA) purification system. Formic acid (HPLC grade) used for buffering was also purchased from Fisher Scientific.

\section{Plant material}

The fruit, leaf, stem and root bark samples of $Z$. leprieurii were harvested in November 2015 (fruit ripening period) from a single tree, growing wild in the Senegalese locality known as Colomba-Bignona $\left(12^{\circ} 46^{\prime} \mathrm{N}, 16^{\circ} 14^{\prime} \mathrm{W}\right)$. The botanical identification of the plant material was performed by Dr. William Diatta from the Department of botanical and pharmacognosy of University Cheikh Anta Diop of Dakar (Senegal).

\section{Plant extracts}

Each plant organ (fruits, leaves, root barks, stems, and trunk barks) has been extracted separately. Plant samples were air dried for a period of four weeks at ambient temperature. The plant material was crushed with an average particle size of $0.2 \mathrm{~mm}$ using a blade miller (Polymix PX-MFC 90D, KINEMATICA AG, Luzern, Switzerland). $50 \mathrm{~g}$ of powder samples were extracted with $3 \times 200 \mathrm{~mL}$ of methanol over 48 $\mathrm{h}$ each time, at room temperature under magnetic stirring. The solutions were combined, filtered through filter paper (PRATDUMAS, Couze-St-Front, France) and evaporated to dryness using a rotary evaporator (Laborota 4000, Heidolph, Schwabach, Germany). The methanolic solutions were evaporated to dryness using a rotary evaporator and the extract yields $(\mathrm{w} / \mathrm{w}$, calculated on a dry weight plant) were $42.2 \%, 18.7 \%, 18 \%$ and $8 \%$ for fruits, leaves, root barks and stems, respectively. Each dried extract was stored at $4{ }^{\circ} \mathrm{C}$ until analysis. Prior to LC-MS 2 analysis, $10 \mathrm{mg}$ of each sample extract was dissolved in $\mathrm{H}_{2} \mathrm{O} / \mathrm{ACN}(1: 1 \mathrm{v} / \mathrm{v})$ to obtain a solution at a final concentration of $100 \mathrm{mg} / \mathrm{L}$. Finally, the solutions were filtered through a $0.2 \mu \mathrm{m}$ polytetrafluoroethylene (PTFE) filter (Whatman, Maidstone, UK).

\section{References compounds and preparation of standard solutions}

All references of flavonoids (98\% purity determined by HPLC) were purchased from Extrasynthese (Geney, France). Solutions of each standard were prepared by dissolving the reference compound in $\mathrm{ACN} / \mathrm{H}_{2} \mathrm{O}(1: 1 \mathrm{v} / \mathrm{v})$ at a final concentration of $5 \mathrm{mg} / \mathrm{L}$. Then, they were filtered with a 0.2 $\mu \mathrm{m}$ PTFE filter. These standard solutions were diluted with $\mathrm{ACN} / \mathrm{H}_{2} \mathrm{O}(1: 1 \mathrm{v} / \mathrm{v})$ to obtain calibration curves with seven points in the concentration range of $0.01-5 \mathrm{mg} / \mathrm{L}$. The calibration solutions were stored at $4{ }^{\circ} \mathrm{C}$ until LC-MS ${ }^{2}$ analysis. A blending solution, which contained the reference components at a concentration of $0.1 \mathrm{mg} / \mathrm{L}$ in $\mathrm{H}_{2} \mathrm{O} / \mathrm{ACN}(1: 1$ $\mathrm{v} / \mathrm{v}$ ), was used as positive control of LC-MS2 analysis of the plant extracts (before and after sample injections).

\section{MS² Conditions}

MS2 conditions were carried on an AB Sciex (Toronto, ON, Canada) 3200 QTRAP linear triple quadrupole fitted with electrospray ionization (ESI) ion source operating in negative mode. High purity nitrogen was used as both a nebulizer and turbo gas. The ESI source was operated with following settings in negative mode; curtain gas: (CUR) 25 psi, nebulizer gas: (GS1) 41 psi, heater gas: (GS2) 65 psi, ion spray voltage (IS): $-4200 \mathrm{~V}$, and temperature: $550^{\circ} \mathrm{C}$. Standard solutions (component concentration: $0.1 \mathrm{mg} / \mathrm{L}$ ) were directly infused at the flow rate of $10 \mu \mathrm{L} / \mathrm{min}$ in the MS/MS apparatus. Multiple EPI mass spectra of each compound were recorded in the range of $\mathrm{m} / \mathrm{z}=50-1000$ at $4000 \mathrm{Da} / \mathrm{s}$. IDA properties were set to select 1 to 2 peaks above 500 counts with an exclusion filter after 5 occurrences for $30 \mathrm{~s}$ with dynamic background subtraction. The software used for data acquisition and data analysis was Analyst 1.5.2 (AB Sciex, Framingham, MA, USA).

\section{LC conditions}

The LC system consisted of a Flexar LC Perkin-Elmer (Waltham, MA, USA) with two Flexar FX-10 LC pumps, a Flexar solvent manager, a 275-Flexar autosampler, and a Flexar LC PE200 column oven. LC analyses were performed on a $100 \mathrm{~mm} \times 2.1 \mathrm{~mm}$ i.d. $3 \mu \mathrm{m}$, LUNA $3 \mathrm{U}$ C18 column (Phenomenex, Torrance, CA, USA) and the column temperature was set at $25^{\circ} \mathrm{C}$. A volume of $10 \mu \mathrm{L}$ of sample was injected using an injection loofcp of $15 \mu \mathrm{L}$ in partial loop mode. The mobile phase consisted of MilliQ water containing $0.1 \%$ formic acid (solvent A) and ACN (solvent B). The flow rate was set at $500 \mu \mathrm{L} / \mathrm{min}$. The column was equilibrated (A:B; v/v) in 90:10 (5 min), and elution was carried out with the following steps; $90: 10$ (2 min), a linear gradient increasing from $10 \% \mathrm{~B}$ to $100 \%$ (14 min), and 100\% B ( 9 $\min )$.

\section{Identification of the components}

To detect 186 components potentially present in the Rutaceae family (commercially available standards) in the studied extracts, we used the method based on LC-MS 2 developed in previous work [4]. The identification of flavonoids in Z. leprieurii extracts was allowed by comparing the retention times, observing the characteristic MRM transitions, and by matching the $\mathrm{MS}^{2}$ spectra of reference compounds.

For each reference compound, a relevant transition of the precursor-to-product ions was detected with the utilization of the multiple reaction monitoring (MRM) mode. Using ESI source operating in negative mode, the precursor ion [M + $\mathrm{H}^{-}$for each of the analytes was determined in MS ${ }^{1}$ full scan tests and the product ions in MS/MS experiments. MRM transitions of each compound were optimized using direct infusion with the following MS/MS parameters: declustering potential (DP), entrance potential (EP), collision cell entrance potential (CEP), collision energy (CE), and collision cell exit potential (CXP). Retention times of reference compounds were determined by $\mathrm{LC}^{-\mathrm{MS}^{2}}$ analysis in the multiple reaction monitoring (MRM). Mass spectra of standard components were performed by the MRM mode followed by an enhanced product ion (EPI) scan, triggered by information dependent acquisition (IDA) criteria. 


\section{Antioxydant activity. ABTS•+-Scavenging Assay}

The ability of extracts to bleach the 2,2'-Azino-bis(3ethylbenzothiazoline- 6-sulfonic acid) radical (ABTS•+) was evaluated according to the method of modified Andreani et al (2013) [33]. ABTS $\bullet+$ was produced by reaction of equal volumes of $7 \mathrm{mM}$ ABTS solution and $2.4 \mathrm{mM}$ potassium persulfate for $16 \mathrm{~h}$, in the dark and at room temperature. The stock solution was then diluted in Milli- $Q$ water to reach an absorbance of $1.00 \pm 0.01$ at $734 \mathrm{~nm}$. Then, $200 \mu \mathrm{L}$ of diluted ABTS $\cdot+$ solution was mixed with $50 \mu \mathrm{L}$ of methanol extract solution $(0-200 \mu \mathrm{g} / \mathrm{mL}$ final concentration $)$. The absorbance at $734 \mathrm{~nm}$ was taken 5 min after mixing using a Tecan Infinite ${ }^{\circledR} 200$ PRO multimode reader (Tecan Group Ltd., Männedorf, Switzerland). Radical scavenging activity was calculated using the following formula:

$$
I \%=100 \times(A b-A s) / A b
$$

where $A b$ is the absorbance of the control reaction and $A s$ the absorbance of the sample. The sample concentration providing $50 \%$ inhibition ( $\mathrm{IC}_{50}$ ) was calculated from the graph of inhibition percentage against relatively to the sample concentration. Tests were carried out in triplicate, and Trolox was used as a positive control.

\section{RESULTS AND DISCUSSION}

\section{Analysis of flavonoid compounds from Z. leprieurii extracts using the LC-MS² Method}

The identification of flavonoids in Z. leprierii extracts was allowed by the comparison of retention times, the observation of characteristic MRM transitions, and by matching the MS2 spectra of reference compounds (Table 1). The mobile phase $\mathrm{H}_{2} \mathrm{O} / \mathrm{ACN}(1: 1 \mathrm{v} / \mathrm{v})$, allowed the separation of targeted compounds of $Z$. leprieurii extracts.

Table 1: Retention times (Tr), multiple reaction monitoring (MRM) transition, and optimized tandem mass spectrometry (MS/MS) detection parameters of four flavonoids.

\begin{tabular}{|c|c|c|c|c|c|c|c|c|c|}
\hline \multirow[b]{2}{*}{ No. } & \multirow[b]{2}{*}{ Compounds } & \multirow[b]{2}{*}{$\operatorname{Tr}(\min )$} & \multicolumn{2}{|c|}{ Transition } & \multicolumn{5}{|c|}{ MS Parameters (V) } \\
\hline & & & $\begin{array}{l}\text { Q1 Mass } \\
\text { (Da) }\end{array}$ & $\begin{array}{c}\text { Q3 Mass } \\
\text { (Da) }\end{array}$ & aDP & bEP & cCEP & dCE & eCXP \\
\hline 1 & Neodiosmin & 8.29 & 607 & 299 & -90 & -4 & -28 & -36 & -4 \\
\hline 2 & Datiscin & 8.34 & 593 & 285 & -95 & -6.5 & -34.1 & -50 & -4 \\
\hline 3 & Rutin & 8.46 & 609 & 301 & -85 & -9.5 & -26 & -36 & -4 \\
\hline 4 & Hesperidin & 8.48 & 609 & 301 & -75 & -4.5 & -32 & -34 & -4 \\
\hline
\end{tabular}

$\mathrm{aDP}=$ declustering potential; $\mathrm{bEP}=$ entrance potential; ${ }^{\mathrm{c} C E P}=$ collision cell entrance potential; $\mathrm{d} C \mathrm{CE}=\mathrm{collision}$ energy; ${ }^{\mathrm{CXP}}=$ collision cell exit potential.

Among the 186 reference compounds tested, four flavonoids were unambiguously identified in one or other of the organ extracts from each plant (fruit, leaf, root barks and stem). These four compounds (table 2) are: one flavone (neodiosmin 1), two flavonols (datiscin 2, rutin 3 ) and one flavanone (hesperidin 4).

The flavonoid content of $Z$. leprieurii extracts showed a variation in the chemical composition according to the parts of the plant. Two of these flavonoids (neodiosmin $\mathbf{1}$ and hesperidin 4) were present in stems and roots, three (neodiosmin 1, rutin 3 and hesperidin 4) in fruits and all four were detected in the leaves. Thus, two glycosylated flavonoids (neodiosmin 1, hesperidin 4) were identified in all extracts. The presence of rutin $\mathbf{3}$ was recognized in fruits and leaves while that of datiscin 2 was reported only in leaves.

Table 2: Identified flavonoids in various parts of $Z$. leprieurii plant

\begin{tabular}{clcccc}
\hline No. & Compounds & Fruits & Leaves & Stems & Root barks \\
\hline 1 & Neodiosmin & + & + & + & + \\
2 & Datiscin & - & + & - & - \\
3 & Rutin & + & + & - & - \\
4 & Hesperidin & + & + & + & + \\
\hline
\end{tabular}

(+): present; (-): absent

Of these four flavonoids, three are detected for the first time in Z. leprieurii, namely neodiosmin, datiscin and rutin. The presence of hesperidin in Z. leprieurii was reported by Tabuti in 2011 [5]. All the flavonoids identified in this study have already been reported in Rutaceae, particularly in citrus fruits; thus, these constituents can be considered as chemotaxonomic markers of the genus Zanthoxylum.

\section{Antioxydant activity}

The antioxidant properties of all extracts were tested regarding their scavenging activities on ABTS •+ radical (Table 3 ). The ABTS ${ }^{\bullet+}$ scavenging activity of extracts decreased in the order of fruit extract $>$ leaf extract $>$ stem extract $>$ root extract. Compared to the reference antioxidant (Trolox: 4.18 $\mu \mathrm{g} / \mathrm{mL}$ ), fruit, leaf and stem extracts had low antioxidant potential with an $\mathrm{IC}_{50}$ of $51.41 \pm 0.94 \mu \mathrm{g} / \mathrm{mL}, 55.10 \pm 2.14$ $\mu \mathrm{g} / \mathrm{mL}$ and $60.66 \pm 4.85 \mu \mathrm{g} / \mathrm{mL}$, respectively. Extract obtained from root barks exhibited very low antioxidant activity (IC I0 $_{50}$ $95.40 \pm 2.27 \mu \mathrm{g} / \mathrm{mL}$ ). Our results cannot be compared to those of the literature because the methods used are not the same.

Table 3: ABTS ${ }^{\bullet+}$-Scavenging Activity

\begin{tabular}{ll}
\hline Samples & $\mathrm{IC}_{50}[\mu \mathrm{g} / \mathrm{mL}]$ \\
\hline Leaves & $55.10 \pm 2.14$ \\
Fruits & $51.41 \pm 0.94$ \\
Root barks & $95.40 \pm 2.27$ \\
Stems & $60.66 \pm 4.85$ \\
Trolox & $4.18 \pm 0.05$ \\
\hline
\end{tabular}




\section{CONCLUSION}

This study reported flavonoid compounds from Zanthoxylum leprieurii and their antioxidant activity. Four flavonoids (neodiosmin, datiscin, rutin and hesperidin) were identified. The different extracts had low antioxidant potential. In perspective, we will quantify these falvonoids.

Acknowledgments: We thank the Ministry of Higher Education and Scientific Research of Senegal, the Cooperation and Cultural Action Department of the Embassy of France in Dakar, and the Territorial Authority of Corsica for their financial support.

\section{REFERENCES}

1. Kähkönen MP, Hopia AI, Vuorela HJ, Rauha JP, Pihlaja K, Kujala $\mathrm{TS}$, et al. Antioxidant Activity of Plant Extracts Containing Phenolic Compounds. Journal of Agricultural and Food Chemistry 1999; 47(10):3954-3962.

2. Ruiz-Ruiz JC, del Carmen Esapadas Aldana G, Cruz AIC, SeguraCampos MR. 9 - Antioxidant Activity of Polyphenols Extracted From Hop Used in Craft Beer. In: Grumezescu AM, Holban AM, editors. Biotechnological Progress and Beverage Consumption, Academic Press; 2020.

3. Kumar S, Pandey AK. Chemistry and Biological Activities of Flavonoids: An Overview. The Scientific World Journal 2013; 2013: e162750.

4. Tine Y, Yang Y, Renucci F, Costa J, Wele A, Paolini J. LC-MS/MS Analysis of Flavonoid Compounds from Zanthoxylum zanthoxyloides Extracts and Their Antioxidant Activities. Natural Product Communications 2017; 12(12):1865-1868.

5. Tabuti JRS. Zanthoxylum leprieurii Guill. \& Perr. In: Schmelzer G.H. \& Gurib-Fakim, A. Wageningen, Pays Bas: PROTA (Plant Resources of Tropical Africa / Ressources végétales de l'Afrique tropicale); 2011.

6. Lamorde M, Tabuti JR, Obua C, Kukunda-Byobona C, Lanyero $\mathrm{H}$, Byakika-Kibwika $\mathrm{P}$, et al. Medicinal plants used by traditional medicine practitioners for the treatment of HIV/AIDS and related conditions in Uganda. Journal of Ethnopharmacology 2010; 130(1):43-53.

7. Kerharo J, Adam JG. La pharmacopée sénégalaise traditionnelle. Paris: Vigot Frères; 1974

8. Noumi E. Les plantes à épices, à condiments et à aromates du Cameroun. Thèse de Doctorat. Université de Yaoundé, 1984.

9. Tatsadjieu LN, Essia Ngang JJ, Ngassoum MB, Etoa FX Antibacterial and antifungal activity of Xylopia aethiopica, Monodora myristica, Zanthoxylum xanthoxyloides and Zanthoxylum leprieurii from Cameroon. Fitoterapia 2003; 74(5):469-472.

10. Gardini F, Belletti N, Ndagijimana $M$, Guerzoni ME Tchoumbougnang F, Zollo PHA, et al. Composition of four essential oils obtained from plants from Cameroon, and their bactericidal and bacteriostatic activity against Listeria monocytogenes, Salmonella enteritidis and Staphylococcus aureus. African Journal of Microbiology Research 2009; 3(5):264-271.

11. Misra LN, Wouatsa NV, Kumar S, Kumar RV, Tchoumbougnang F. Antibacterial, cytotoxic activities and chemical composition of fruits of two Cameroonian Zanthoxylum species. Journal of Ethnopharmacology 2013; 148(1):74-80.

12. Talontsi FM, Douanla-Meli C, Laatsch H. Depsidones from an Endophytic Fungus Chaetomium sp. Associated with Zanthoxylum leprieurii. Zeitschrift Für Naturforschung $B$ 2014; 68(11):1259-1264.

13. Ngane AN, Biyiti L, Zollo PA, Bouchet PH. Evaluation of antifungal activity of extracts of two Cameroonian Rutaceae: Zanthoxylum leprieurii Guill. et Perr. and Zanthoxylum xanthoxyloides Waterm. Journal of Ethnopharmacology 2000; 70(3):335-342

14. Matasyoh J, M Talontsi F, M Ngoumfo R, Chepkorir R. Larvicidal activity of acridone alkaloids from Zanthoxylum leprieurii against the malaria vector Anopheles gambiae. The Natural Products Journal 2011; 1(2):121-124.

15. Tchinda AT, Fuendjiep V, Sajjad A, Matchawe C, Wafo P, Khan $\mathrm{S}$, et al. Bioactive compounds from the fruits of Zanthoxylum leprieurii. Pharmacologyonline 2009; 1:406-415.

16. Ngoumfo RM, Jouda JB, Mouafo FT, Komguem J, Mbazoa CD Shiao TC, et al. In vitro cytotoxic activity of isolated acridones alkaloids from Zanthoxylum leprieurii Guill. et Perr. Bioorganic \& Medicinal Chemistry 2010; 18(10):3601-3605.

17. Choumessi AT, Loureiro R, Silva AM, Moreira AC, Pieme AC Tazoacha A, et al. Toxicity evaluation of some traditional African spices on breast cancer cells and isolated rat hepatic mitochondria. Food and Chemical Toxicology 2012; 50(11):4199-4208.

18. Dongmo PM, Tchoumbougnang F, Sonwa ET, Kenfack SM, Zollo $\mathrm{PH}$, Menut C. Antioxidant and anti-inflammatory potential of essential oils of some Zanthoxylum (Rutaceae) of Cameroon. International Journal of Essential Oil Therapeutics 2008; 2(2):82-88.

19. Bouba A, Njintang YN, Scher J, Mbofung CMF, others. Phenolic compounds and radical scavenging potential of twenty Cameroonian spices. Agriculture and Biology Journal of North America 2010; 1(3):213-224.

20. Womeni HM, Djikeng FT, Tiencheu B, Linder M. Antioxidant potential of methanolic extracts and powders of some Cameroonian spices during accelerated storage of soybean oil. Advances in Biological Chemistry 2013; 03(03):304.

21. Fish F, Waterman PG. Chemosystematics in the Rutaceae II. The Chemosystematics of the Zanthoxylum/Fagara Complex. Taxon 1973; 22(2/3):177-203.

22. Guetchueng ST, Nahar L, Ritchie KJ, Ismail FMD, Wansi JD, Evans A, et al. Kaurane Diterpenes from the Fruits of Zanthoxylum leprieurii (Rutaceae). Records of Natural Products 2017; 11(3):304-309.

23. Calderwood JM, Fish F. Screening for tertiary and quaternary alkaloids in some African Fagara species. Journal of Pharmacy and Pharmacology 1966; 18(S1):119S-125S.

24. Fonzes L, Winternitz F. Étude des alcaloides de Fagara léprieurii, Engl._II. Phytochemistry 1968; 7(10):1889-1890.

25. Fish F, Waterman PG. Alkaloids from two Nigerian species of Fagara. The Journal of Pharmacy and Pharmacology 1971; 23:132S-135S

26. Waterman PG, Gray AI, Crichton EG. A comparative study on the alkaloids of Zanthoxylum leprieurii, Z. lemairei and Z. rubescens from Ghana. Biochemical Systematics and Ecology 1976; 4(4):259-262.

27. Adesina SK. The Nigerian Zanthoxylum; chemical and biological values. African Journal of Traditional, Complementary and Alternative Medicines 2006; 2(3):282-301.

28. Reisch J, Adesina SK, Bergenthal D. Constituents of zanthoxylum leprieurii fruit pericarps. CIII: Natural product chemistry. Pharmazie 1985; 40(11): 811-812.

29. Ekundayo 0, Oguntimein B, Adeoye A. Volatile constituents of the essential oil of Zanthoxylum leprieurii. Fitoterapia 1986; 57(4):267-269.

30. Lamaty G, Menut C, Bessiere JM, Aknin M. Aromatic plants of tropical Central Africa. II. A comparative study of the volatile constituents of Zanthoxylum leprieurii (Guill. et Perr.) Engl. and Zanthoxylum tessmannii Engl. leaves and fruit pericarps from the Cameroon. Flavour and Fragrance Journal 1989; 4(4):203-205.

31. Fogang HPD, Tapondjou LA, Womeni HM, Quassinti L, Bramucci M, Vitali LA, et al. Characterization and biological activity of essential oils from fruits of Zanthoxylum xanthoxyloides Lam. and Z. leprieurii Guill. \& Perr., two culinary plants from Cameroon. Flavour and Fragrance Journal 2012; 27(2):171-179.

32. Oyedeji AO, Lawal OA, Adeniyi BA, Alaka SA, Tetede E. Essential Oil Composition of Three Zanthoxylum Species. Journal of Essential Oil Research 2008; 20(1):69-71.

33. Andreani S, De Cian MC, Paolini J, Desjobert JM, Costa J, Muselli A. Chemical variability and antioxidant activity of Limbarda crithmoides L. essential oil from Corsica. Chemistry \& Biodiversity 2013; 10(11): 2061-2077. 